How can I work within the government's perspective of 'Gifted and Talented' but still remain true to my own living values?

\title{
Joy Mounter
}

\section{Master's Assignment January 2008}

'Gifted and talented children are those who have one or more abilities developed to a level significantly ahead of their year group (or with the potential to develop these abilities).'

\author{
'In England the term 'gifted' refers to those pupils who are capable of excelling \\ in academic subjects such as English or History. 'Talented' refers to those \\ pupils who may excel in areas requiring visio-spatial skills or practical abilities, \\ such as in games and PE, drama, or art.'
}

(Standards site,12 August 2008)

\section{Context for the Reader}

I have taken a step back from my last assignment. Stopped to consider the question and the space I now occupy. My story through my assignments has described and evaluated my journey of discovery with the children I have taught. Each assignment builds and widens my perspective, the sequencing and structure of the text reflecting the feeling of the journey, the uncertainty and sometimes even the amazement. The writing is for me, to clarify and enfold me into the moment from a perspective of hindsight, not to share or explain but at most to offer a glimpse into my world. It helps me to clarify the educational influence on my learning, and the children. It is written not as a summary for the reader, but to clarify for myself events with the perspective of hindsight, impacting and developing my own learning, but written as the journey, to draw the reader in and understand through the flow or muddles the feeling and learning struggle that took and is taking place, even now though the writing. The moments that quietly are missed, alone just droplets, but together declare a new perspective and understanding. Challenging perceptions, offering an alternative future. Now. To see through my eyes and understandings via the words I select. To engage myself, the educationalist open to exploring my 'shoes' and the Academy.

My journey has explored the development of self and understanding of learning skills for life, of the children in my care, whilst trying to fulfil the requirements of meeting the needs of the individual child.

\section{Summary}

I am in the unique position as Headteacher to develop policy in my school, influencing the experiences of staff, parents and children, as well as a wider audience through my essays and published work (Mounter,2008). This assignment will be in the form of a narrative using the living theory action research approach (Whitehead and McNiff,2006). It will weave together my previous work, relating my own ontological living values and 
the development of my talents as an educator, in relation to creating an enriching learning 'space' that responds and helps to develop the talents of my pupils as they produce their own gifts. Rayner $(2009$, p.8) explores 'space' we create and discusses inclusionality, the flow form of dynamic inclusion, a fluid continuum within a co-creative energy flow. My intention through this essay is to contribute to the professional knowledge-base of education by exploring my relational and responsive talents as an educator (which form my ontological values) and the educational relationships I have with my pupils. The voice of my pupils will also form part of this exploration helping to examine and demonstrate my educational influence in the pupils development and understanding of their own gifts and talents as 'knowledge creators' and 'proactive learners'.

Through the Tuesday Master's group at Bath University and my accounts being available on the Internet as well as presentations to colleagues, I have shared my writings, video extracts and work by the children, as well as my living values and developing living theory. I have considered comprehensibility, truth, rightness and authenticity of my accounts, testing the criteria for validity (Habermas, 1976) of my research and findings through the understanding of another person and developing a shared understanding by the discussions, developing and enriching my own embodied, living theory and values.

'Moreover, communicative action can continue undisturbed only as long as participants suppose that the validity claims they reciprocally raise are justified.'

(Habermas, 1976, p.2-3)

\section{Introduction}

(www.standards.dfes.gov.uk/giftedandtalented/identification/gandt/)

- I read the government statement above with a sad heart and determination that opportunities in my school will be open and encouraging for all learners. Can we identify and label children who are only aged $4-11$ years of age, children who are just beginning to explore the world around them and themselves, as gifted and talented?

- Should we then as teachers, educators of future generations enable and offer opportunities in a narrow spectrum for these few children.

- Do we believe that all children are a gift from God in themselves, all with differing gifts and talents that as educators it is our responsibility to help them to discover and explore?

- Can I identify $10 \%$ of children in my school and label them at this point in time as gifted and talented?

- What then do I label the other children as? 
- Shouldn't my aim be to enhance opportunities and a love of learning, developing the gifts and talents of all the children as stated in 2020 Vision document and National Curriculum?

'Foremost is a belief in education, at home and at school, as a route to the spiritual, moral, social, cultural, physical and mental development, and thus the wellbeing, of the individual. Education is also a route to equality of opportunity for al.'

(National Curriculum, Values and Purposes 1999)

Perhaps this view by Albert Einstein summarises it:

'I have no special talents. I am only passionately curious.' (Einstein,A.1999)

The Eastern and Christian view of gifts and talents draws my attention and does not fight some aspects of government policy although we are also asked to define and categorise children's potential. Are we not then confining and limiting opportunities for children to explore, develop and excite themselves as a learner?

"The major cultural dichotomy affecting educational provision for the gifted and talented is between the largely Eastern perception - 'all children have gifted potential' - and the largely western one - 'only some children have gifted potential'." (Freeman, 2002, p.9)

Through 'gifted potential' is Freeman presenting the Eastern view that all children have gifts and talents they should have opportunities to explore and develop as Thompson (1998) also explores or that all children have the potential to be 'gifted' with the right stimulating environment?

One of the issues facing schools of whether all children are gifted or whether all children have gifts is difficult to separate the subtle meanings. Is this the same argument or can it mean completely different things?

The words 'gift' and 'gifted' have different levels of meaning. Thompson (1998) argues that 'gift' is a term that we use to describe people's best qualities; whereas, 'giftedness' is a technical, professional term that educators use to describe really smart children who require differentiated educations. He defines 'social gifts' and 'educational gifts' as requiring different understanding and responses from the educational establishment. The gift of kindness for example, is a gift to be wished for but is in the social sense and not an educational gift. I am drawn to his understandings and the separation that all children have gifts and talents, but all children are not necessarily gifted.

Renzulli (1991) explores supporting gifted children and the risks we run in the future if these children are not identified and supported. 
'lose our quest for excellence in the current move to guarantee equity will undoubtedly result in a disappointing, if not disastrous, education for our most potentially able children.'

(J. Renzulli, 1991)

The arguments surrounding the use of gifted and talented related to children in education and whether we can catagorise young children has taken on a new perspective as I explore the same writings and research with the new explanation from Freeman, differentiating our view of gifted and having gifts. This gradual change in perspective can be seen through the writing of Barry Hymer, the change from identifying and how we successfully manage the education of gifted and talented pupils to his more recent work, emphasising the need for enabling and creating space for children to explore and create their gifts and talents.

I have seen my interests and energies shift from the identification and appropriate 'management' of 'gifted learners' (the given state) to the exploration and advocacy of approaches to 'creating' gifts and talents' (Hymer, 2007.p23)

Whilst exploring the writings available to develop my own skills as an educator I was initially drawn by the ideas of Hymer (2007) that we can create a 'space' enabling children to develop their own gifts and talents.

The more I read I can feel a tangible pull and quandary even within the publications we are given as a school from the government. This 'living contradiction' as highlighted by Whitehead and McNiff (2006) leads to a conflict in our approach to 'gifted and talented' children. The values and purposes of the National Curriculum as stated previously describes equality of opportunities and personalised learning, meeting the needs of every child, where as we are then asked to identify as gifted and talented $10 \%$ of pupils. But if we are tracking all children and planning appropriately aren't we also meeting their needs already?

Is there equality if we are catagorising children and opportunities they have, rather than creating an environment and curriculum that stimulates learning, curiosity and the creation and development of gifts and talents?

'Talent is an amalgam of high sensitivity; easy vulnerability; high sensory equipment (seeing, hearing, touching, smelling, tasting-intensely); a vivid imagination as well as a grip on reality; the desire to communicate one's own experience and sensations, to make one's self heard and seen.' (Hagen, U.1999)

This quote by Uta Hagen draws and links with my research by Barry Hymer (2007) in that the space we create is so important to stimulate and not confine young minds, but to provide opportunities for them to create their own gifts and talents, sharing them and sparking new growth. 
It's kind of fun to do the impossible. (Disney. W, 1999)

\title{
Relational and Responsive Talents as an Educator
}

\author{
'How often am I guilty of conjuring up a bright and fanciful show in the \\ classroom only to realize that I am putting my students to sleep? How often do I \\ make unilateral decisions about what is important and should be integrated into \\ their lives?' \\ (McNamee,2006.p1)
}

When I first found this quote it pulled a slightly guilty heart-string. If we are honest we have all asked questions, even open questions, but have a right answer we weave towards through the children's answers. Beginning to question my role in the classroom I asked my class of 7 and 8 year olds how we learn. The frightening and first method that was suggested was by 'listening to the teacher'. This had me even more worried and anxious about my own role and practice.

Reading on I found this as another sign, building on my readings from Hymer (2007):

I would like to propose, therefore, that we bracket the metaphor of teaching as a technique or method for conveying knowledge and consider the potentials opened by approaching teaching as a form of collaborative conversations.......' (McNamee,2006.p3)

The creation of this space and understanding of the relational gifts we have to offer each other and our diversity creates the spark of ideas and the co-creational learning, wisdom and knowledge.

'What we might deem, in a perfectionist framework, to be a flaw in human nature, our vulnerability and proneness to error, is actually vital. It is the source of our creative spirit'

(Rayner,2008,p.3)

This I found by chance on web site of quotes but it emphasises my belief in the necessity of not catagorising and creating expectations for children to live up to.

'Only as high as I can reach can I grow, only as far as I seek can I go, only as deep as I look can I see, only as much as I dream can I be.'

(Ravn, Karen. 1999)

Creating opportunities for exploration into how the children believed they thought, learned, remembered and created ideas was a fascinating process and enabled the understanding that sometimes there is no right or wrong answer, we can speculate and learn together. After several months exploring learning together I asked again how we learn and was interested in how perspectives had changed because the children had experienced different approaches and had been encouraged to lead sessions for us and 
other classes. It was scary at times, the feeling of stepping into the unknown, having sessions unplanned in the traditional sense and allowing questions and plans by the children to develop. Often a child would ask a thought provoking question or suggest an activity they felt would deepened the classes understanding of themselves and their values.

Bassey (1992) states creating education through research is slow and time-consuming and most of the time we cannot afford to do it. But nevertheless, it is the most potent way forward. He highlights the 'slavish' repetition following historic models of education, but he recognises the power of research to create worthwhile education. My action research has taken two strands as the children develop and research, creating their own embodied knowledge and values along side my own. Both elements supporting and challenging our thinking and beliefs. We therefore both bring our embodied knowledge for validation and accreditation by creating our own separate (but jointly influenced) living educational theories demonstrating for myself my educational influence on my own learning and that of my pupils as well as their creation of wisdom and knowledge influenced by the space that I have created. Whilst working with the children in my care for an academic year my research has enabled me to realise the power of the research process itself and the research I have carried out to help me to clarify for myself, my own talents in developing the 'space' Hymer (2007) talks about that has enabled my class to develop and articulate their own living theory and talents. Part of the excitement of this process has been the children's growing awareness of themselves as a person and as a learner and the educational system they are part of.

McNiff (2007) discusses how her 'story' or journey becomes her living educational theory, as revealing new living standards of judgment for educational enquiries through my journey. The creation and development of my own talents as an educator creating this 'creation space' (Hymer, 2007) enabling the children to recognise and nurture their own gifts and talents are explored through the relationships, interactions and responses of my children. My personal meaning of educational responsibility is revealed as I work through the tensions I feel between conforming to government policies on gifted and talented pupils and living my educational values as fully as I can. Retaining my integrity in the educational relationships I have with my pupils is very important to me as I meet the needs of my children. I am drawn to the writings of Biesta (2006), who points out that it is educationally significant to be concerned with the 'coming into the world' of my children as unique, singular beings:

'We can, however, also look at learning from a different angle and see it as a response. (Biesta, 2006,p.27)

The children have looked at the work of West-Burnham, (2006) who describes 'deep learning' and thought about their understanding of that space within themselves. We sat and wrote together about what we felt the space was like, where it is, what goes in there, can we access it all of the time or do we think on different levels or plains at different times? 
This is the space the children feel the creation of knowledge takes place. I explored this concept of 'deep learning' by West-Burnham, (2006) and the children using creative vocabulary to record their thinking in Mounter (2007). But it is the creation of knowledge which the children believe happens in this space that interested them.

JA 'Deep learning feels like peace and challenging'

OL 'Everyone can be a deep learner. I am a deep learner sometimes. My head thinks I am a deep learner, but my heart thinks I am not quite.

We also generated vocabulary that we felt describes that space we create and use, deep learning: Please see Appendix One.

The children explored the meaning for them of 'deep learning' the place where they collect ideas and save them. The place where ideas take on new meanings and value to them as they grow and the reflections change. During a discussion with child ' $\mathrm{A}$ ' at lunch time he explained how he missed thinking about learning in his new class. The conversation came around to a discussion we had shared a year before when he was challenging Belle Wallace's learning theory using the TASC Wheel(Wallace et al, 2004)

This child had read and found out about an educational learning theory written by an adult and had the confidence through his own growth as a learner to challenge it. To believe in his own ideas, and ability to create knowledge and challenge the perspective of an adult. This for me was a reflection of the time and space for learning I had created, something different and valued as a space for co-creation of knowledge and wisdom, for exploring understandings in a safe, creative and challenging way. I had discovered in myself a talent for creating a unique learning space encouraging self reflection and 'understanding growth' as well as the confidence to say we are the learners, experts in learning together. Child A began describing his previous belief that the TASC Wheel should be three dimensional and not two dimensional as Belle Wallace created it. He then explained that his brain was now better at thinking and he believed the TASC Wheel should actually be five dimensional and not three as he previously said. He had decided that the dimensions of time and movement influenced learning too. He then talked about other things he had been learning; unaware of the amazement I was feeling!

Dads and Hart(2001) discuss the importance of methodological inventiveness. I tried to create a space where the relationship between the children and myself was fluid, trusting and a shared responsibility for our learning and research.

'Teachers become coaches - encouraging the children to open up questions for research for themselves.'(Toffler, 2006)

This was understood by child A and led to the contemplating of learning over a long period of time, without any formal structure or planned support.

'But we had understood far less well that how practitioners chose to research, and their sense of control over this, could be equally important to their 
motivation, their sense of identity within the research and their research outcomes.' (Dadds \& Hart, p.166, 2001)

This was very true in my class, the more the children explored themselves as learners, the more the children questioned things around them as facts. A key question that I could not answer for the children was:

'Why is it only grown ups that write about learning, when it is us that do the learning? Why haven't they asked us?' (child N)

Kellett (2005) talks about the possibilities and rewards for young researchers, her book being aimed at children aged 10 to 14 , where as my class were only aged 6,7 and 8 . But she does describe the benefits of teaching research processes to children to create knowledge. The children challenged the world around them, the theories they read about and ideas held about learning.

Action research is well documented as being 'reflective' (McNiff, 2002) and will encourage the children to not only reflect on their experiences as a learner, but also selfinner reflection of themselves. What makes them enthusiastic as a learner, what strengths do they have? How or can they overcome their fears as a learner?

From this, the action reflection cycle enabled the children to apply what they knew about learning opportunities, themselves and others in the class and to apply their understanding and begin theorising about learning for themselves.

'Children are acknowledged as experts on their own lives and if adults genuinely want to understand children and childhood, better ways to seek out child perspective and unlock child voice must be sought.' (Alderson, 2000; Mayall, 2000; Christensen and Prout 2000)

As part of their reflections the class felt we had learned a lot about ourselves and our 'places' as they called them, and that they changed sometimes. Please see Appendix Two.

Their reflections demonstrate clearly the shift from the beginning of our work together when the children felt they just had to listen to me to learn. This demonstrates the fluid roles within the classroom and the change in the perception of learning and responsibility for learning and as a learner.

Working through the action research cycle as co-learners helped me to realise the impact I have on the children in my care, enabling me to work with the children to develop self awareness of their talents, which they confidently articulated, but at the same time realise the impact I was having, in creating and having a relationally dynamic awareness of the space and boundaries we created and in which I respond continuously, often unnoticed to the educational needs of the children. 
Hutchinson (1998, 373-379) writes about the: '...empowering nature of research which takes the form of action research.

Connelly and Clandinin(1999) intrigued me with their exploration of a teacher's classroom and the impact of government, social and school policy using a landscape metaphor. They describe how the professional knowledge forms the landscape which is made up of many components and influenced by many people, places and things.

'We view the landscape as narratively constructed: as having a history with moral, emotional, and aesthetic dimensions. We see it as storied. To enter a professional knowledge landscape is to enter a place of story.'

(Connelly and Clandinin.1999. p.1)

For me this frames the belief that I or the children have a story to tell, one we passionately believe in that forms part of our living values. A story that is on going even when we are not together to support each other, but belief that is embedded in us and was reinforced by child A. They talk about the influence of the in-classroom landscape and the out-of-classroom landscape. The out-of classroom landscape influences and forces the direction of the in-classroom landscape and forms the current perspective from government, school and society.

'a place filled with knowledge funnelled into the school system for the purpose of altering teachers' and children's classroom lives.'

(Connelly and Clandinin.1999.p.2)

It is this out-of-classroom landscape that I shut out at the door and live my values. Together we have carried out action research, challenging perceptions of children as researchers and the living theories of others, it is now time to open the door and share our research and present it, to contribute to the professional knowledge base of education.

Whitehead and Huxtable(2007) discuss working with a living theory approach to the skills, understandings and sophistication not only in creating gifts but also in the child's emerging understanding of their own living values and theories. They highlight the findings of my own research in the child's sense of well being and voice. The confidence to challenge the world around them and believe they can co-create knowledge and present it to the world. And be heard, not listened to, but heard!

'through this approach we are working for the individual to learn about, and to develop, their own living standards. These contribute to their decisions as to how they will develop their talents and what gifts they value and will work to create and offer, to whom and in what manner which will enable them to contribute to their own and other's wellbeing.' (Whitehead,J.\&Huxtable,2007) 
As the children's confidence grew they challenged the perceptions of those around them as being the expert learners. The children wrote to Belle Wallace (2004) and asked if she was going to write another book as they liked her learning theory, but felt their understandings had moved on further than her book. On You Tube you can watch (www.youtube.com/watch? $\mathrm{v}=\mathrm{hH} 2-5 \mathrm{xexbAQ}$ ) an extract of the children discussing the changes they felt should be made and how they had worked on them, even making a model. My educational influences on learning and my affirmation of inclusionality with my class is seen expressed in the educational relationship with my pupils as I respond to their needs in relation to their learning. Our 'gift' is for each other and the profession as we freely give our writings as a contribution to the professional knowledge-base.

I often find images carry more meaning than words, although I usually need words to communicate the significance the image has for me. I also find conversations with others about images help to develop shared meanings of the values that help to constitute my productive life. I call these shared meanings about embodied values the affirmations of inclusionality and the representation of these meanings, visual narratives.' (Whitehead,2005)

Another moment captured on film at the end of a long day for me encapsulates my living values and how learning should feel. For the children it shares their joy and pleasure at the end of a task. For me it shows the relationships within the class, the space I have created and the sense of pleasure at solving a difficult problem as well as the shared pleasure and affirmation from the child watching in the background. It sums up my living values and educational theory, my passion for creating a space enabling children to discover and grow their own as well as my own, gifts and talents.

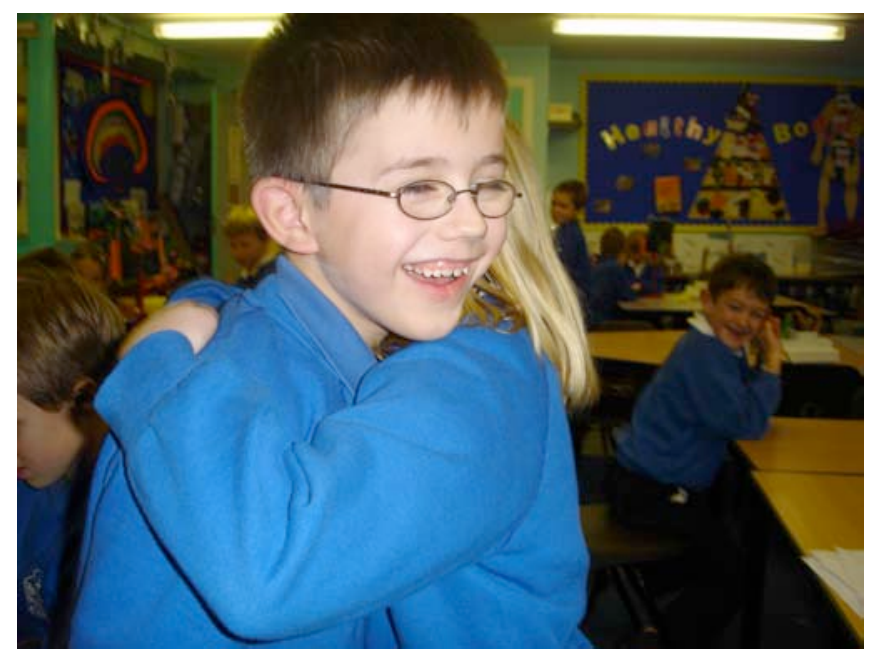

From this understanding of the theories of others the children's self belief as experts encouraged them to write their own learning theory. This took only a short session to outline and another two sessions to complete. The children clearly show their talent for creating knowledge encompassing their embodied educational values and living theory. See appendix Three. 
We have combined our voices through shared action research and responsibility for learning enhancing our educational influence through producing and communicating our educational theories and living values. I have developed my own understandings and talent for creating an in-classroom-landscape that enfolds learners in a shared sense of time and space, breathing life into hidden talents and latent gifts. But for myself it also inspires and feeds my soul. Korczak (Efron, S. 2005) describes how you need to continually 'get' to be able to give, nurturing development.

'Only by getting can you give, only by growing in one's own spirit can one collaborate in the development of others.'

(Efron,S. 2005. p145-156)

I have deliberately not labelled my conclusion to this essay. All of my writing reflects within the text, formation and combination of the words the feel of the journey I have experienced, reflected through the essay for the reader. At times to struggle with the meaning and the moment and at others to flow quickly. Conclusion implies the ending, a tying together of threads into a tidy package, but the journey isn't finishing, this is merely another step. The series of essays I have written combine as steps along the paths I have discovered; it cannot be tidied to end here, but must just link to the next. Step, moment, research, reflection, essay. I am inspired by the reflection and memory of the paths I have forged, but the potential for discovery I can feel is just out of reach. At the moment! 4499 


\section{Appendix One page 7}

'It is all tangly and fiddly. It's gloomy and dark. Easy learning becomes hard new learning becomes harder. I'm going to learn until it comes to the edge. It's tingly and magic , it's got loads of wisdom in it and shiny. It helps out until learning breaks out.' FM and OL

Old, ideas, new, rough, smooth

Over flowing

Stringy, sticky, gooey

Tangled, tangly

Clear, sparkling, spark, flash

Dark, light

Full to the brim

Colourful, swirl, swirly

Flow, flowing, stumbling

Messy, unordered

Deep, digging

Finding, searching

Mixed up, muddled

Puzzled

Jiggling, wobbling

Frizzy

Weird

become

Easy learning becomes hard. New learning becomes old until it becomes gooey, sticky, icky, weird, deep flashes now and again make a sound when slick, then get all mixed up at the end.

Until it curls around

Until

I'm going to learn, it comes to a stop

Comes to the edge

So it helps out until learning breaks out

Until at the end it gives up the dinosaur

Wake up

But flashes hopefully, then the dinosaur is tired, then goes to sleep

And then tries again.

By AR and ZD 


\section{Appendix Two}

Child D2 said we swapped around. Meaning that sometimes I was the teacher and sometimes not. We opened this up further and recorded some of the roles. Child $\mathrm{K}$ and others agreed that initially they thought I as the teacher would tell them the things they needed to learn and they would practice them and then know them. I knew everything. But the list on the board of our roles was very interesting and different:

We are the teachers (children)

Mrs Mounter as the teacher Mrs Mounter as the learner

Us as the learners (children)

We learn together, sometimes

'I like learning together best; it feels nice like I am important' Child A 


\section{Appendix Three}

\section{Children's Learning Theory}

The starting point was the form of the TASC Wheel and the letters standing for different words. The children began discussing ideas for a special word to call their theory. Child 'A' quickly came up with 'QUIFF' and the children liked the sound of the word. The next step for them was deciding what each letter should stand for. They talked together around the circle sharing ideas whilst I acted as scribe on the whiteboard. The process from start to finish including thinking of the word and what each letter meant only took half an hour, this was with the agreement of all the children.
Q questions
$\mathbf{U}$ understanding
I I am important
F feelings
F focus

The discussion was focused, there were no disagreements about what each letter should stand for. Children of all abilities shared ideas and added detail to the ideas. The whole class are really pleased with their initial idea and then wanted time to think about it before adding more detail behind QUIFF. This point of reflecting and coming back to the task was their own idea and seemed to give all of the children time to come up with strong ideas and have a lot to share when they came back together.

Child D quickly pointed out the following day that the 'I' he had thought of for 'I am important' is in the middle of the word, just like we are in the middle of our learning. Child A is confident all aspects of learning are in QUIFF because we control the type of learner we are with how we are feeling or believe we have learned about ourselves.

The children like the physical representation of QUIFF as a wheel and wanted a visual picture of QUIFF. In this picture by child A, The pyramid represents our learning. The base is ' $Q$ ' questions, base of all learning and the widest part of our learning pyramid. Our focus helps us answer those questions, persevere, which appears like an egg floating in the questions. Another child explained how they had put an eye at the top of the pyramid because we are most important and stop or let all of the learning happen. Child B explained how he had put knowledge of 'things' as he called them in the triangle, but of himself higher because that is more important and harder to learn about. The whole picture is surrounded by a rainbow as that provides the skills for us to learn. 


\section{Bibliography}

1. Bassey, Michael (1992); Creating Education through Research Pub. Educational Research Journal. Vol 18 no 1, 3-16

2. Biesta, G. J. J. (2006) Beyond Learning; Democratic Education for a Human Future. Boulder; Paradigm Publishers.

3. Connelly, F.M. \& Clandinin,D.J. (1999) Shaping a Professional Identity: Stories of educational practice,Ontario;Althouse Press.

4. Dadds, M. \& Hart, S. (2001) Doing Practitioner Research Differently, London; RoutledgeFalmer.

5. Disney. Walt (1999); Thinkexist[Online] available from: www.Thinkexist.com[Accessed 1.1.2009].

6. Efron, S (2005) Janusz Korczak: Legacy of a Practitioner-Researcher. Journal of Teacher Education. 56: 145-156

7. Einstein, A. (1999); Thinkexist [Online] available from: www.Thinkexist.com[Accessed 1.1.2009].

8. Habermas, J. (1976) Communication and the evolution of society. London : Heinemann.

9. Hagen, U. (1999) Thinkexist[Online] available from: www.Thinkexist.com[Accessed 1.1.2009].

10. Hutchinson, B. (1998), Learning Action Research and Managing Educational Change - Improvement in Careers Education: A Case Study of Managerialism in Action? Educational Management and Administration, Vol 26, pp. 373379.

11. Hymer,B. (2007) How do I understand and communicate my values and beliefs in my work as an educator in the field of giftedness? [Online]available from: http://people.bath.ac.uk/edsajw/hymer.shtml [Accessed 2.1.09]

12. Hymer, B., Whitehead, J. \& Huxtable, M. (2009) Gifts, Talents and Education: A living theory approach.West Sussex:Wiley Blackwell.

13. Kellett, M. (2005) How to Develop Children as Researchers: A Step-by -Step Guide to Teaching the Research Process. London:P.C.P Publishing. 
14. Korczak, J. (1919) Legacy of a Practitioner-Rsearcher Pub. Journal of Teacher Education Online.2005;56[Online] available from http://jte.sagepub.com/cgi/content/refs/56/2/145 [Accessed 9.01.09].

15. McNamee, S. (2006) Relational Practices in Education:Teaching as Conversation in Anderson \& Gehart (2006) Invitations: Applications of Post modern Collaborative Therapy. New York: Brunner Routledge.

16. QCA (1999) National Curriculum, Values and Purposes[Online] available www. http://curriculum.qca.org.uk/key-stages-1-and-2/Values-aims-andpurposes).

17.Raven, K. (1999); Thinkexist $t$ Online] available from: www.Thinkexist.com[Accessed 1.1.2009].

18.Rayner,A.(2008) Natural Inclusion from adversity with love;[Online]available: http://www.spanglefish.com/mariessite/index.asp?pageid=72148[Accessed [2.1.09]

19.Renzulli, J. (1991) The Reform Movement and the Quiet Crisis in Gifted Education in Gifted Child Quarterly, Vol. 35, No. 1, 26-35.

20.Thompson, M.C. (1998) A speech delivered at the Indiana Association for the Gifted 1998 Annual Conference[Online]available from: www.About.com[Accessed 1.1.2009].

21.Toffler, A. (December 2006) Quotes. Retrieved on 11 January 2009 from www.nswppa.org.au/pwinspire.hmtl.

22.Wallace, B. (2004) Thinking Skills and Problem Solving: An Inclusive Approach. London; David Fulton.

23. Whitehead, J. (2005) Living inclusional values in educational standards of practice and judgement. Keynote for the Act, Reflect, Revise III Conference, Brantford Ontario, $11^{\text {th }}$ November 2005. Retrieved on $11^{\text {th }}$ January 2009 from http://www.jackwhitehead.com/monday/arrkey05dr1.htm.

24.Whitehead, J. \& Huxtable, M. (2007); How can inclusive and inclusional understandings of gifts/ talents be developed educationally? Paper presented to the World Conference for Gifted and Talented Children on from Local Worlds of Giftedness To Global, University of Warwick.

25. Whitehead, J. \& McNiff, J. (2006); Action Research Living Theory; London; Sage. 